\title{
Improvement of Rights to Buildings Property to Be Living House at Land Office in the Pekalongan City
}

\begin{abstract}
Karsono ${ }^{1}$, Desi Ana Yustianita ${ }^{2}$ and Amin Purnawan ${ }^{3}$
Abstract. The purpose of this study was to analyze: 1) the implementation of the improvement of the status Broking become Properties for Residential Land Offices Pekalongan. 2) Barriers and solutions in the implementation of the improvement of the status Broking become Properties for residences in the Land Office Pekalongan. Method approach in this study is juridical sociological. The data used are primary and secondary data obtained through interviews and literature, while data analysis was done by descriptive analysis.

Results of the research results can be concluded: 1) The increase in status Broking become Properties for Residential Land Offices Pekalongan begins from filling the application letter, attaching a land certificate, a copy of building permit, a letter from the village head, a copy of the letter Tax Payable (SPPT), copy of land and Building Tax (PBB), Examination Identity applicant agree or disagree with land ownership being requested, research documents received, the applicant made a payment, examine documents and land book certificate new, then Head of surrender documents and land books and certificates to the officers of sub. PHI to do the bookkeeping and when it is complete then the clerk handed the documents to be archived to the archive officer, and submit a certificate to the applicant. 2) The difficulties experienced that an applicant seeking to register an increase in land rights for residences often do not include the application for the building permit, the public is less aware of the procedures and conditions should be attached at the time of filing the application. The solution that the Land Office of Pekalongan socialization, it aims to provide information and understanding to the community.

Keywords: Improved Status of Land; Right of Building Usage; Owner Right.
\end{abstract}

\section{Introduction}

In human life the soil has a sense and has a dual function, namely the social assets of the land is a means of fastening social unity among the people for life and living, and land as a capital asset, namely as a capital factor in development and has grown as an economic good which is very important at a time as a commercial material and object of speculation. ${ }^{4}$ The conception of the land in accordance with Act No. 5, 1960, known as the Basic Agrarian Law (BAL) of Article 4 is earth's surface that covers the body the authority to use the land, water and space above it. In this sense the land includes land that are already something existing rights on it and clung something right according the legislation in force..$^{5}$

Tenure, which is fixed in accordance with Act No. 5, 1960, under Article 16, namely: ${ }^{6}$ 1) The right to land is fixed, covering Owner Right (HM), Right Bussines Usage (HGU), Right of Use (HP), Rental Rights and Right to Build. The right use building has a limited

\footnotetext{
${ }^{1}$ Students Master of Notary, Sultan Agung Islamic University in Semarang email karsono123@gmail.com

${ }^{2}$ Students of Master of Law, Faculty Of Law, Universitas Islam Sultan Agung email desiana17@gmail.com

${ }^{3}$ Faculty of Law Universitas Islam Sultan Agung, Semarang.

${ }^{4}$ Achmad Robbie, 2007, Hukum Pengadaan Tanah Untuk Kepentingan Umum, Malang,Bayumedia, p.1

${ }^{5}$ Anonim, 2007, Petunjuk teknis Direktorat Survey dan Potensi Tanah, Deputi Survey, Pengukuran dan Pemetaan BPN RI, Jakarta, p. 6

6 Ibid, p. 16
} 
period of time should be increased to the property in order to have legal certainty for the rights holder. Increased HGB become the property still must be registered with the Land Office where the object is located.

House and land is a fundamental requirement for legal certainty that human beings need to be done to obtain a guarantee of land registration on the ground, while the status of the land is registered in addition to Right, there are other lesser rights such as HGB, HP, HGU. With the lower right by the people deemed inadequate for a limited time period and need no further charge to extend its rights and legal position is less strong when compared with Owner Right (HM). Therefore, rights holders whose status is lower than the property can increase the status of a property so that land and houses owned and occupied to the status of property rights legal position of the most powerful and secure than rights over land to another.

Decision of the National Land Agency No. 6 of 1998 on the Granting of Property Rights to Land For Home stay is basically the arrangements for granting property rights to land former Broking whose width is not more than $600 \mathrm{~m} 2$ (six hundred square meters), but there are also contains a provision on the restriction of the maximum ownership land property rights may be owned by one family bati ie not more than five (5) fields sum total area of 5,000 $\mathrm{m} 2$ (five thousand square meters) and if the person concerned will propose a land rights to the field of the sixth, the National land Agency is not provide more property will be given to him but Broking or rights over other land. $^{7}$

Since 1961, according to the Indonesian Government Regulation No. 10 of 1961, a notary is no longer entitled to make land rights transfer agreement. Powers was subsequently given to PPAT specially appointed by the Minister of Agrarian ago, now the National Land Agency (hereinafter abbreviated as BPN), and headdistrict $s$ also given authority as PPAT. The Notary Public in general also doubles as the Land Deed Official. PPAT (Land Deed Official) only have the authority to make the deed over land rights that are within the scope of work. Deed is an article of legal act used as evidence at a later date. ${ }^{8}$

In Pekalongan, many citizens who have the status Broking. Due HGU only have limited time, to prevent conflict in the future, given the number of Pekalongan population continues to increase, it should HGU for residential is increased to the property in order to have legal certainty for the rights holder. Increased HGB to Right still must be registered with the Land Office where the object is located. National Land Agency (BPN) as the agency that issued the certificate of land rights, berwenangpula to cancel land title certificates based on asascontrarius actus. The National Land Agency is a representation country in land revocation case against an individual right or institution. ${ }^{9}$

Based on this background, lifted the title "Improvement Of Rights To Buildings Property To Be A House At Land Office In The Pekalongan City" . This research is trying to answer the problem of implementation of the improvement of the status Broking Become Properties for Residential Land Offices Pekalongan, as well as barriers and solutions in the implementation of the improvement of the status Broking Become Properties for residential Land Offices Pekalongan.

\footnotetext{
${ }^{7}$ Ibid, p.13

${ }^{8}$ Achmad Sulchan, 2017, Akta Notaris Menggunakan Media Elektronik, SINT Publising, Semarang, p. 50

${ }^{9}$ Mudakir Iskandar Syah, 2014, the Land Acquisition for Public Interest: Remedies Affected Communities Liberation and Revocation Rights, Publisher gem Literacy, Jakarta, p.3
} 


\section{Research methods}

The method used in this research is juridical sociological. Juridical Sociological is a legal research using secondary data as the data first, followed by primary data or data field. ${ }^{10}$ Specification of the research is descriptive. Primary data were collected by interview. Type of interview used in this study using a free guided interview, is a combination of free and guided interview. ${ }^{11}$ Secondary data is data obtained from a review of the literature or the review of the literature or library materials related to the problem or research materials that are often referred to legal materials. ${ }^{12}$ Analysis of the data used in this study is qualitative analysis that the data have been obtained from field studies and literature will be collected and grouped systematic then qualitatively analyzed in order to obtain an overview and understanding of the systematic and comprehensive to address the problems examined.

\section{Results and Discussion}

\subsection{Implementation of improvement status of Building Usage Being Right Properties To House Land Office Live Pekalongan}

Land has a function and a very important position in a variety of life, especially as a place for living / housing. The rise development in various fields of life caused land into a commodity that has economic value is very high and difficult to control. Such conditions, mainly due to increasing land needs very rapidly while the availability is limited, so do not often lead to conflict over land, whether it be a conflict of ownership, and conflict concerning the use / land priority itself.

Given today's increasingly limited land, especially in large cities, while total demand increasing, especially for a place to stay, then under these conditions the government has taken a policy of broad restrictions on ownership. This policy was taken based on the balance in order to land freehold do not all fall to those who can afford to buy the land alone. This is an important factor, because of the many people who need the land for the benefit of the land for the benefit of the residence, while they are mostly made up of people who can not afford. In addition, not a few people capable of acquiring land but only bought it for "dumped" or neglect, in the sense just purchased but not used properly, or are abandoned or vacated. ${ }^{13}$

Currently the major concern of the National Land Agency is the certainty of land ownership. Then the land policy always is directed at improving the utilization and use of land in a fair, transparent and productive, with emphasis on the rights of the people, as well as by spatial harmonious and balanced in the corridor of the legislation in force based on the public administration system which can be accounted for. Land policy is described in more detail in the context of land covering an orderly land law, land administration discipline, orderly land use and orderly maintenance of the land and the environment.

Communities in Indonesia, especially in Pekalongan complained about the maintenance process Right Building Usage (HGB) to the Certificate of Land Ownership (SHM).

\footnotetext{
${ }^{10}$ Amiruddin, 2012, Pengantar Metode Penelitian Hukum, Rajagrafindo Persada, Jakarta, p.15

${ }^{11}$ Ibid, p. 84

${ }^{12}$ Mukti Fajar dan Yulianto, 2010, Dualisme Penelitian Hukum Normatif dan Empiris, Pustaka Pelajar, Yogyakarta, p. 156

${ }^{13}$ Adrian Sutedi, 2018, Peralihan Hak Atas Tanah dan Pendaftarannya, cetakan.9, Sinar Grafika, Jakarta, p. 23
} 
Partially complains costs, and administrative systems. Certificate changing the legal basis is the State Minister or Head of BPN No. 6 1998. Status SHM certainly higher than HGB. HGB have a validity period of time, usually 20 years or 30 years. The validity period of the HGB, should be extended and would require a fee, whereas SHM has no time restrictions. So, in order not to be bothered by matters HGB extension expired, you should just increase the status becomes Properties. ${ }^{14}$

Conditions that must be completed submission improvement dalamproses Right of Right to Build (HGB) Being Owner Right (HM), namely:

- HGB original certificate.

- A copy of Building Permit (IMB) residence.

- Copy SPPT-UN (Payable Income Tax Property Tax) Current year.

- Copy of Identity Applicant form of Identity Card \& Family Card (KTP and KK).

- PM 1 from the village stating that the house used for residential (in homes did not have IMB).

- Power of Attorney specially, if the maintenance to certain parties.

One disadvantage of the Right to Build (HGB) is not signaled as the land owner, but only allow the use of land, such as constructing buildings on the land to open a business or residence. This certificate also has a term, namely a maximum of 30 years. After expiration, then the need to renew and no renewal fees HGB. If not, then it must return the land to the owner, the state, managers, or individual.

The relevant regulations on the granting of Property Rights is as follows: ${ }^{15}$

- Broking or right to use the land for residential houses belonging to Indonesian citizens an area of $600 \mathrm{~m}^{2}$ (six hundred meters) or less, on the request in question be removed and given back to the former holders of rights to the Property.

- Land Broking or right to use the land for residential houses belonging to Indonesian citizens an area of $600 \mathrm{~m}^{2}$ (six hundred meters) or less that has expired and is still owned by the former holders of such rights, upon request of the concerned given Right to the former holders of rights.

Implementation of the improvement of the status of land from Broking become Properties for housing as regulated in Decree of the State Minister of Agrarian Affairs / Head of National Land Agency Number 6 of 1998 on the Granting of Land Belonging to House Live. To land Right Building Usage (HGB) with an area of $600 \mathrm{~m} 2$ or less can apply To the Land Office at the district / municipal, public means Pekalongan may apply to the Land Office of Pekalongan. Then the applicant should know before applying for each plot is being applied for should not be more than $2000 \mathrm{~m}^{2}$, it is mentioned in Article 4 paragraph 2 of the Decree of the State Minister of Agrarian Affairs / Head of National Land Agency No. 6 of 1998. This restriction applies only to the request Rights belonging to the whole land or part of the land used for House Live. ${ }^{16}$

The process of implementation of the improvement of the status Broking into Right's House Land Office Live Pekalongan namely: ${ }^{17}$

- The applicant must fill out a written request Property Rights over land for residential houses in the Land Office Pekalongan submitted in writing to the Head of the Land Office.

\footnotetext{
${ }^{14}$ Interviews with staff Registration Rights and Land Office information Pekalongan, March 15, 2019

${ }^{15}$ State Minister for Agrarian Affairs / Head of National Land Agency Number 6 of 1998 on the Granting Flak Owned Land for Residential, Article 1 (1).

${ }^{16}$ Interviews with staff Tenure and Land Ownership Land Office Pekalongan, March 15, 2019

${ }^{17}$ Ibid
} 
- The applicant must also attach the relevant title deed in land rights for an increase of Broking into Properties for the certificate could provide legal certainty to the holders of the rights concerned and as legal evidence in his possession.

- The evidence should be included in the use of land for housing in the form of:

- Included a copy of building permit from the competent authority certifying that the building has been used for residences.

- Letter from the village chief or village local lay of the land stating that the building is used for housing.

- The application should be accompanied by enclosing copies of the Notice of Tax Payable (SPPT) and a photocopy of Land and Building Tax (PBB).

- Properties for granting of land for residential, applicant used the identity applicant to be examined about the ownership of the land petitioned. Such information contained in the certificate being applied for improvement of their rights.

- Evidence of acquisition of land and buildings on which the building stands.

- After all the necessary paperwork is complete, the document submitted to the counter II (Counters reception and delivery of the letter of a technical nature) where the officer conducting research documents received. Documents examined is the completeness of which is required in the application Properties on the land for housing.

- Once completed in counter II, III applicant came to the counter to make payments to the petition on the ground Properties. III clerk on duty to make a payment application.

- Head of division Registration Rights and Information (PHI) tasked to examine the document. Documents examined are the applicant's name listed in the Identity, is the same as that contained in the certificate of Right to Build (HGB). If there are differences in the name, the applicant is required to include a description of the applicant's statements were noted by the local village chief. After it makes a disposition or make the concept of the book as well as land and new certificates and certificates write off old land books.

- Once approved by Head of division, the documents and the concept of land as well as the new certificate is submitted to the Section Head of Measurement and Land Registry to examine the document and a new certificate of the land book. Once approved, the Head of the Section of Measurements and Land Registration will be initials on the land book and the new certificate, and then forwarded to the Head of the Land Office.

- Head of the Land Office in charge of examining the application for completeness and accuracy as well as the documents and books concept of land and a new certificate. Once approved, the Head of the Land Office affix the initials on the land book and the new certificate. Further, the head office submitted the documents and books as well as a certificate of land to the executive officer of division PHI.

- The executive officer of the IRC held division bookkeeping, then handed the document to the clerk III to do the bookkeeping. Furthermore, the documents handed to the clerk IV.

- IV counter officer has a duty to record the results of the job submission list and record the number on the certificate. When it is complete then the clerk handed the documents to be archived to the archive officer, and submit a certificate to the applicant. 


\subsection{Obstacles and solutions in the implementation of the improvement of the status Broking into Right's House Live in the Land Office Pekalongan.}

In Pekalongan there are some people who tend to ignore or do not care about the status of their property. One reason is the lack of knowledge about the procedures of SHM. In the process of improving the status of Broking become Properties for residences, the Land Office of Pekalongan experiencing some constraints, namely: ${ }^{18}$

- Applicants who will register the increase of land rights for live houses are often not equipped with the application for Building Permit (IMB) of the land requested for improved rights.

- The public is less aware of the procedures and conditions should be attached at the time of filing the application. As a result of the lack of such knowledge can be an obstacle in the National Land Agency in carrying out procedures that increase the delay in the completion of an increase in the Land Rights.

Some of these obstacles occur because it is caused by several factors, among others: ${ }^{19}$

- Lack of cooperation between the National Land Agency Pekalongan with the village officials in order to educate people to become more aware of the problems of land, especially in improving Broking become Properties.

- The lack of public knowledge about the importance of the process of improving land rights.

- Officers of the Land Office could be less rigorous in examining and notarize the file that should do re-examination. This is one cause of delays in the completion of the change of rights. Registration Head of division rights of information and the actual information is the time needed to make improvements to land rights is 5 (five) days, but due to the volume of work available so that the implementation of the increase in land rights to be longer than a predetermined time.

To overcome the constraints increase Broking become Properties for housing faced, the Land Office of Pekalongan needs to socialize with regard to the Transitional Broking into property rights to the public, it is aimed at understanding the information and to correct public perception considers that the improvement of the status Broking become Properties for home too complicated and expensive. While in other solutions to overcome the constraints above is to improve the facilities and infrastructure to support the performance of the Land Office of Pekalongan.

\section{Closing}

\subsection{Conclution}

Based on the description above, the conclusions in the writing of this thesis are:

- Implementation of the improvement of the status Broking become Properties for residences in the Land Office of Pekalongan are filling petition Property Rights over land for residential houses in the Land Office Pekalongan, attach a land certificate, include a copy of Building Permit (IMB), a certificate from the village head or village, attach a copy of the Notice of Tax Payable (SPPT) and a photocopy of Land and Building Tax (PBB), verifies the identity of the applicant, the study documents received, After the completion of counter II, the applicant came to the window III to make payments, Head of division Registration Rights and Information (PHI)

\footnotetext{
${ }^{18}$ Interviews with staff Land Tenure and Property Capital Land Office Maghfiroh Pekalongan, S, AP, March 15, 2019

${ }^{19}$ Ibid
} 
tasked to examine the document, if approved and submitted to the Section Head of Measurement and land Registry to examine the documents and certificates of land new book, Head of the land Office affix the initials on the land book and the new certificate. Further, the head office and submit documents and certificates to the land book division executive officer of the IRC, the counter clerk IV has a duty to record the results of the job submission list and record the number on the certificate. When it is complete then the clerk handed the documents to be archived to the archive officer, and submit a certificate to the applicant.

- Obstacles and solutions in the implementation of the improvement of the status Broking become Properties for Residential Land Offices Pekalongan.

- Applicants who will register the increase of land rights for living houses are often not equipped with the application for Building Permit (IMB) of the land requested for improved rights.

- The public is less aware of the procedures and conditions should be attached at the time of filing the application.

To overcome the constraints above, the Land Office of Pekalongan socialization, it aims for understanding information and to correct perceptions of people who think that improving the status of Broking become Properties for living house too complicated and expensive. As for other solutions to overcome the constraints above is to improve the facilities and infrastructure to support the performance of the Land Office of Pekalongan.

\subsection{Suggestion}

After the conclusion of the results of research and discussion, the authors provide suggestions as follows:

- Society should be more active in seeking information about the land, especially on the improvement of the status of building usage right into property rights to residential houses, because it is very important to ensure the ownership status of land used as a residence Ruma. Because if negligent, then people itself will be harmed, because the status of the land will be owned by the State.

- Land Office Pekalongan need to provide socialization on land, as well as cooperating with the apparatus of society, so that the process of increasing Broking become Right quickly completed within the specified time and to attract people to apply for rights to land petitioned rights.

\section{Bibliography}

\section{Books}

[1] Achmad Robbie, 2007, Hukum Pengadaan Tanah Untuk Kepentingan Umum, Malang,Bayumedia

[2] Achmad Sulchan, 2017, Akta Notaris Menggunakan Media Elektronik, SINT Publising, Semarang

[3] Adrian Sutedi, 2018, Peralihan Hak Atas Tanah dan Pendaftarannya, cetakan.9, Sinar Grafika, Jakarta

[4] Amiruddin, 2012, Pengantar Metode Penelitian Hukum, Rajagrafindo Persada, Jakarta

[5] Anonim, 2007, Petunjuk teknis Direktorat Survey dan Potensi Tanah, Deputi Survey, Pengukuran dan Pemetaan BPN RI, Jakarta 
[6] Boedi Harsono, 2003, Menuju Penyempurnaan Hukum Tanah Nasional, cetakan kedua, Universitas Trisaksi, Jakarta

[7] Eko Yulian Isnur, 2012, Tata Cara Mengurus Segala Macam Surat Rumah dan Tanah, Jakarta Selatan, PT.Buku Seru

[8] Mudakir Iskandar Syah, 2014, Pembebasan Tanah Untuk Kepentingan Umum: Upaya Hukum Masyarakat yang Terkena Pembebasan dan Pencabutan Hak, Penerbit Permata Aksara, Jakarta

[9] Mukti Fajar dan Yulianto, 2010, Dualisme Penelitian Hukum Normatif dan Empiris, Pustaka Pelajar, Yogyakarta

[10] A.P. Parlindungan, 2008, Komentar atas Undang-undang Pokok Agraria, Mandar Maju, Bandung

[11] Supriadi, 2010, Hukum Agraria, Cetakan Keempat, Sinar Grafika, Jakarta

[12] Urip Santoso, 2010, Hukum Agraria Kajian Komprehensif, Jakarta, Kencana Prenada Media Group

\section{Legislation}

[1] Act of 1945

[2] Act No. 5 of 1960 On the Basic Regulation Agrarian

[3] Act No. 4 of 1992 on Housing and Settlements

[4] Government Regulation No. 40 of 1996 on leasehold, Broking and Right to Use Land

[5] Act No. 24 of 1997 on Land Registration

[6] Government Regulation No. 37 of 1998 on the regulations Land Deed Official Position

[7] State Minister for Agrarian Affairs / Head of National Land Agency Number 6 of 1998 on the Granting Flak Owned Land for House Live

[8] Minister of State for Agrarian Affairs / Head of National Land Agency Number 5 of 1998 on the Amendment Broking Or Right to Use Land For House Live loaded Mortgage becomes Properties.

[9] Government Regulation No. 20 of 2015 on Land Agency 